\title{
Czech perceptions of the rise of China: a survey among university students
}

\section{Yu-Wen Chen ${ }^{1,2}(\mathbb{D}) \cdot{\text { Yufan } \mathrm{Hao}^{3}}^{3}$}

Received: 17 August 2018 /Revised: 18 March 2019 / Accepted: 11 April 2019 Published online: 26 April 2019

(C) The Author(s) 2019

\begin{abstract}
China has increased its investment and influence in Central-Eastern European (CEE) countries through the " $16+1$ " framework in 2011 and the One Belt One Road (OBOR) initiatives in 2013. Given China's rising influence, this paper explores civilian views of China in the Czech Republic. Using survey analysis of 663 respondents in 11 Czech universities, we find that our respondents' impression of China is neither negative nor positive. By contrast, they do not have a good impression of Russia. Their impression of Japan is the best. Our respondents recognize that China is the most influential player in Asia. Albeit divided, there is a tendency for respondents to believe that China will surpass the USA as the world's leading power, but they cannot reach consensus on whether such development will be peaceful or not. Our survey also finds out that, while the Czech government wishes to get closer to China politically and economically, citizens are somewhat divided on various dimensions of issues concerning China. This is a pattern that continues from the past. The 2013 change of political landscape in the Czech Republic does not seem to have altered many of the societal responses to China.
\end{abstract}

\section{Introduction}

In recent years, the People's Republic of China (PRC) has increased its investment and influence in Central-Eastern European (CEE) countries. The " $16+1$ " framework, for instance, is a platform that was created in 2011 to facilitate China's cooperative interactions with 16 CEE countries (Hooijmaaijers 2019) B. Eleven of these countries

Yu-Wen Chen

julie.chen@helsinki.fi

Yufan Hao

haoyufan@cuhk.edu.cn

1 Chinese Studies, Department of Cultures, University of Helsinki, Unioninkatu 38 A, 00014 Helsinki, Finland

2 Department of Asian Studies, Palacky University, Olomouc, Czech Republic

3 Chinese University of Hong Kong (Shenzhen), Shenzhen, China 
are members of the European Union (Bulgaria, Croatia, the Czech Republic, Estonia, Hungary, Latvia, Lithuania, Poland, Romania, Slovakia, Slovenia) while five of them are candidates for European Union (EU) membership (Albania, Bosnia and Herzegovina, Macedonia, Montenegro and Serbia) (Fig. 1).

CEE countries carry a certain Soviet legacy and have traditionally been supportive of the US policies in the region. However, the rising Chinese influence in CEE countries might start to change the region's traditional ties with the USA. Furthermore, the fact that these countries have a greater need than other Western European countries for Chinese investment might generate a split in Europe. The richer Western European countries can afford to be more hesitant towards Chinese investments than CEE countries for fear of the potential risks that might accompany the opening up of some sensitive sectors. Western European countries' feeling of exclusion in $16+1$ meetings could also exacerbate the split within Europe. There are also concerns put forward by observers about the potential alliance of the aforementioned $11 \mathrm{CEE}$ countries that are simultaneously EU members (Chang and Pieke 2018; Fallon 2014). Although this has not yet occurred, the possibility of the formation of a pro-China lobby in the EU to affect policy-making towards China in Brussels cannot be excluded. Last but not least, with the advent of Beijing's much-propagated One Belt One Road (OBOR) initiative in 2013, China's ambition in expanding its influence in Europe becomes even more apparent. In this context, CEE countries are considered important connecting points for OBOR. Hungary, for example, was the first European country to sign a memorandum of understanding with China to promote OBOR in Europe in 2015.

Among CEE countries, analysts have observed that the Czech Republic has a rather inconsistent approach towards the PRC (Fürst and Pleschová 2010). It is inconsistent in the sense that, economically, the Czech Republic has welcomed economic engagement with China while, politically, some politicians, non-governmental organizations (NGOs), and the Czech media are known to be critical of China's human rights record.

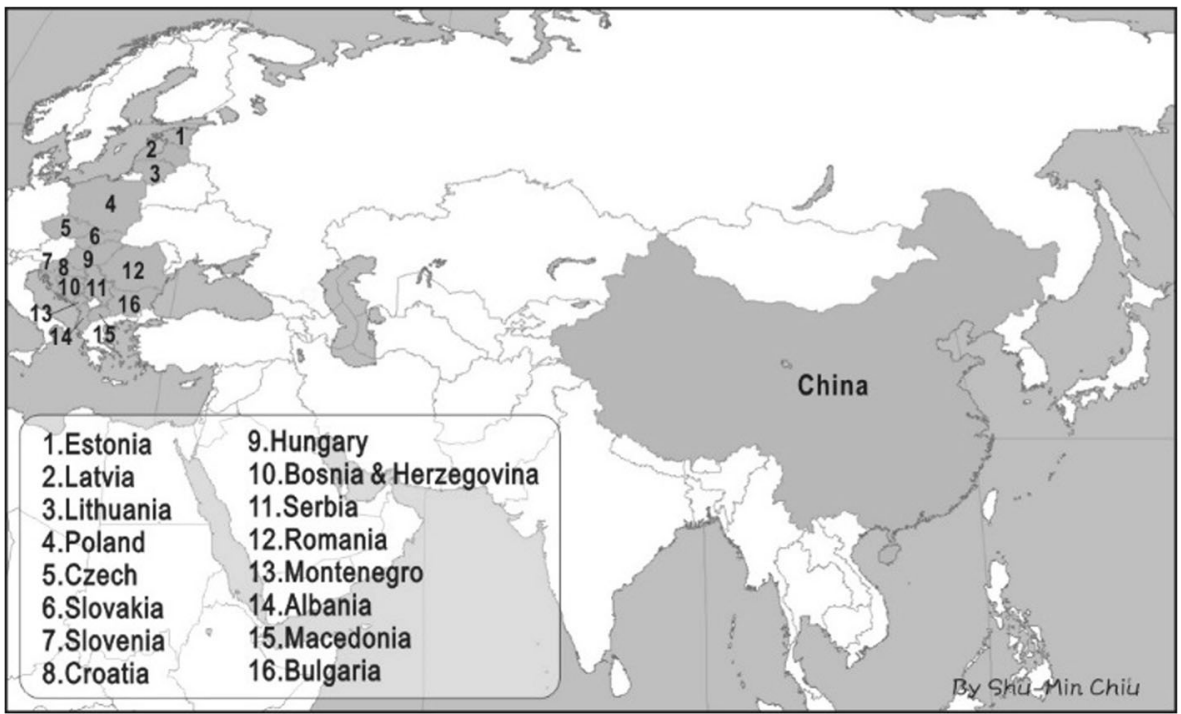

Fig. 1 Countries in China's $16+1$ initiative 
This is in contrast to other CEE countries such as the neighboring Slovakia, which avoids any issues that would upset the country's relations with China. While human rights issues are never the main focus of the Czech Republic's foreign relations with China, due to the sympathy of a certain sector of society for Chinese dissidents, Taiwan, and Tibetan representatives in exile, the Czech Republic often gives outsiders the impression that the country has a more moralistic approach towards China than it actually does.

Observers of China's relations with CEE countries, however, have noted that recent Czech relations with China are becoming warmer and forgoing their potential tendency for moralistic judgment of Beijing (Turcsanyi 2015). On September 3, 2015, the country's president, Miloš Zeman, was the only head of state of the EU to attend the V-Day parade commemorating the 70th anniversary of the victories of the AntiJapanese War of the Chinese people and the World Anti-Fascist War held in Beijing (Turcsanyi 2015). Another example was the visit of the Czech foreign minister to China in 2014, the first of such visits in 15 years.

Some analysts have attributed this switch of attitudes to the 2013/2014 reshuffle of powers in Czech domestic politics. Except for that of the Minister of Defense, all the main foreign policy positions are occupied by social democrats (Dostál and Eberle 2015). This gives social democrats the power to carry out their preferred pragmatic approach towards China. Others have contended that CEE countries are not seen by the Chinese government as important in world politics. But Beijing is slowly "upgrading" CEE countries in its foreign policy, as shown in the $16+1$ initiatives and OBOR. Economic prospects brought about by these new initiatives have prompted CEE countries, including the Czech Republic, to strengthen their bonds with Beijing (Turcsanyi 2014). Regarding the Czech Republic, most of China's activities are more concerned with the acquisition of businesses, rather than starting businesses.

At the level of foreign relations, Prague is becoming more and more welcoming towards Beijing. We are interested in knowing how ordinary citizens in the Czech Republic perceive this change of Czech-Chinese relations, their impression of China in general, and how they view the rise of China in world politics. Although public opinion does not directly translate into the Czech foreign policy with China, it is certainly one of the factors that policy-makers could consider when forming their policy towards China (Chu et al. 2014). Furthermore, in recent years, China has put tremendous resources into its public diplomacy, using Confucius Institutes and tourism to influence the global public opinion of China (Chen and Duggan 2016). While scholars have different views of China's actual soft power to make itself attractive to people in other countries, the Chinese government continues its soft power diplomacy (Nye 2005). It is thus intriguing to know whether people in CEE countries such as the Czech Republic do have a benign view of China, given the increase in Chinese initiatives targeting this region.

To this end, we use primary survey analysis of 663 Czech university students, conducted in autumn 2015 and spring 2016, as well as qualitative interviews with scholars, to understand the views of ordinary Czech citizens. Our survey is in line with a number of similar efforts undertaken in other regions of the world, for instance Liu Kang, Tianjiang Shi, and John Aldrich's National Image Project (2009); the Asian Barometer survey; and the Washington D.C.-based Center for Strategic and International Studies, which have compared elite views and/or public opinions in Asian Pacific 
countries concerning the rise of China (Green and Szechenyi 2014; Aldrich et al. 2014; Lam et al. 2010; Chu et al. 2014).

In a recent Afrobarometer survey (2014-2015), there is an attempt to follow the Asian Barometer survey by using similar survey instruments to evaluate public opinion of China in various African countries. It is clear that increasingly consistent efforts are being made to measure how China is received by people in different parts of the world. Between 2014 and 2016, surveys were also carried out in Central Asia, adopting measures from Asia Barometer survey (Chen and Günther 2018; Chen and JiménezTovar 2017; Chen 2015).

Apart from the empirical value of these survey results, they theoretically contribute to our testing of one important debate in the field of International Relations (IR) on the implication of China's rise in the world (Shambaugh and Yahuda 2008; Mearsheimer 2010; Katzenstein 2012; Shih and Yin 2013; Zhao 2015). Whether China poses threats or brings forth peace into the world cannot be measured purely by its political, economic, and even military powers or its proclaimed intentions. The perceptions of other countries matter and will affect how their countries form policies towards China, which could bring either harmony or confrontations to bilateral relations and world peace. This paper exactly seeks to explore such important issue and with a particular focus on the Czech citizens' views of China.

In the following paper, we begin with an overview of the relations between the Czech Republic (and its predecessor, Czechoslovakia) with China from the early twentieth century to the present. This allows us to see the fluctuations in Czech foreign relations with China. Political decisions might not reflect the views of ordinary citizens. The review in the second section focuses on political decisions and allows us to understand the motivation of political elites in handling relations with China. The third section introduces our survey that focuses on citizens' views. The fourth part presents our survey analysis and interpretation. While the survey analysis presents the view of Czech respondents in our current era, we seek to explore whether the current view is a continuation of the past one or if Czech society has started to form different opinions about China.

\section{Czech-Chinese relations}

Czechoslovakia was one of the first western countries to recognize the PRC when the new country was founded in 1949. Upon recognizing the PRC on October 4, 1949, Czechoslovakia ceased its relations with the Republic of China (ROC, also known as Taiwan) the next day. Fürst and Pleschová (2010) comment that the support for the PRC came about because of economic interest, "political romanticism" favoring China, and a deficiency of any negative historical experience of China.

This condition facilitated bilateral exchanges in various forms, such as political and cultural interactions until the 1960s, when the Sino-Soviet schism began to distance Czechoslovakia from Beijing (Cheng 2015; Lin 2015). China criticized the Soviet-led military crackdown on the Prague Spring movement (Fürst and Pleschová 2010). Despite the political schism, interest in the Chinese culture and traditions still appealed to the general public and to sinologists (Lomová and Zádrapová 2015). Although China tried to improve its relationship with CEE countries in the 1970s, Czechoslovakia, as an 
anti-Chinese satellite of Moscow, was not able to mend its relationship with China until the second half of the 1980s, when political, commercial, cultural, and academic exchanges resumed (Fürst and Pleschová 2010). This short period of relatively benign relations, however, started to change again after the Velvet Revolution in 1989.

The new president, Václav Havel, was known for his moralistic diplomacy that emphasized democratic values and human rights. In this vein, he had offered support for Chinese dissidents and Tibetan representatives in exile. However, one should not take this as the entire Czech approach towards China. Czechoslovakia cared about economic and cultural relations with Beijing in addition to its interest in more moralistic matters. This is also true after 1993, when the Czech Republic was formed out of Czechoslovakia.

In other words, an intriguing mixture of moralistic and pragmatic approaches was a feature of Czech relations with China. One may describe this as the Czech Republic's incoherent behavior towards China (Fürst and Pleschová 2010). Underneath such inconsistency is the fragmentation of Czech society regarding the issue of China. The Czech media and some politicians tend to be critical of China on these issues. The support for Tibet in the Czech media, according to Fürst and Pleschová (2010), originated from a reflection of Czech society on its totalitarian past. However, political elites have never really formed a consensus on the issue of Tibet and human rights in China. Overall, the society and the country still value economic engagement with China.

It is worth noting that the "irritant" in Sino-Czech relations does not come solely from a sector of society's sympathy for human rights issues. The presence of the Taipei Economic and Cultural Office (TECO), a de facto Taiwanese diplomatic representation in Prague since 1993, and the establishment of the Chiang Ching Kuo International Sinological Center at Charles University Prague in 1996, to some extent gave Taiwan's unofficial diplomacy a breakthrough in Prague, a development that is not welcomed by the PRC (Fürst and Pleschová 2010).

With regard to the "success" of Taiwan's diplomacy in the Czech Republic, there are various factors. CEE countries generally have a desire for economic investment and Taiwan's strategy to use economic incentives to lure political support can partly explain this success (Tubilewicz 2007). However, one cannot ignore the fact that the Czech Republic was not very important to China to begin with. Beijing has reserved attitudes towards the Czech Republic because it is one of Moscow's former satellites. Had the Czech Republic not joined the North Atlantic Treaty Organization (NATO) in 1999 and the EU later in 2004, the Czech Republic would never have gained any prominence in China's diplomatic game. This context has offered Taiwan and the Czech Republic more space to pursue their respective interests (Fürst and Pleschová 2010).

As an example of how EU membership helped increase the Czech Republic's importance to Beijing (Fürst and Pleschová 2010), 2 years after the EU accession, the first PRC investment, Changhong Europe Electric (a joint venture with the Czech PPF Group) took place in 2006. Even so, at times, the Czech government still provoked disturbances in its relationship with China, such as condemning Beijing's actions in the Tibetan unrest in March 2008 and the boycott by various Czech politicians of the Beijing Olympics in the same year.

All of this began to change when, in 2013, social democrats began to rise to power in the Czech government. As noted earlier, the dominance of the left camp in the current government has pushed a more pragmatic approach towards China. Jaroslav 
Tvrdík, for instance, is the head of the Czech-China Chamber of Collaboration and adviser to the Czech Prime Minister on China. The Czech-China Chamber of Collaboration, of which the members include Škoda Auto, has clear commercial interests in China (Dostál and Eberle 2015).

Despite the elite's wish to get closer to China after the 2013 change of government, it is intriguing to know whether ordinary citizens would agree with the government's approach or, as the past has shown us, if Czech society remains divided on such an issue. It is in this context that we seek to use survey analysis to gain a glimpse into the current views of Czech citizens on China.

\section{Method and data}

The survey questions are mostly adapted from a long-term project of one of the authors on surveying civilian views on the rise of China in Japan, the Philippines, and South Korea. The same sets of questions were adjusted for the Czech survey. For instance, the original question does not include South Korea for comparison. Given South Korea's increasing trade flows with the Czech Republic (Tseng 2013; Dostál and Eberle 2015), including both imports and exports, we have added South Korea for comparison. The questionnaire was originally written in English and later translated into Czech, to gauge respondents' general impression of China, perceived influence of China on world affairs, perceived power of China in the future, and perceived Sino-Czech relations.

Due to resource constraints, we used a convenience sample of university students in Palacký University in Olomouc, Masaryk University and Mendel University in Brno, Silesian University in Opava, University of South Bohemia in České Budějovice, University of West Bohemia in Pilsen, Tomas Bata University in Zlín, and University of Hradec Králové in Hradec Králové, as well as University of Economics, Charles University and Metropolitan University Prague in Prague (see Fig. 2).

Various social science projects use a similar kind of sampling strategy of students, as this is the most practical approach to glean the data (Hao and Su 2007; Guo and Feng 2012; Chen et al. 2014; Chen and Günther 2018; Chen and Jiménez-Tovar 2017). Sampling only university students can set limits on statistical inferences. The majority of the students are young, but this does not take away from their value because the younger generation will be the leaders or decision-makers of the country in the future.

We allowed the survey to be conducted either online or offline. For instance, the survey for the University of Economics in Prague was conducted online. With the permission and assistance of course lecturers, we distributed a link to the respondents. In other universities (e.g., Metropolitan University Prague), we went to classes to distribute the questionnaire directly. In online and offline surveys, respondents were briefed about the purpose of the survey before filling out the questionnaire. It normally took about 15 to $20 \mathrm{~min}$ for students to complete the questionnaire.

In the end, 690 questionnaires were returned. Twenty-seven of them, however, were filled out by international students from countries such as Vietnam, Kazakhstan, Belarus, Ukraine, and Russia. It is interesting to see that international students in the Czech Republic tend to come from countries with former Soviet influence and ties.

Besides these 27 observations, 50 of the questionnaires were filled out by students from Slovakia. We removed the 27 international students' observations but kept these 


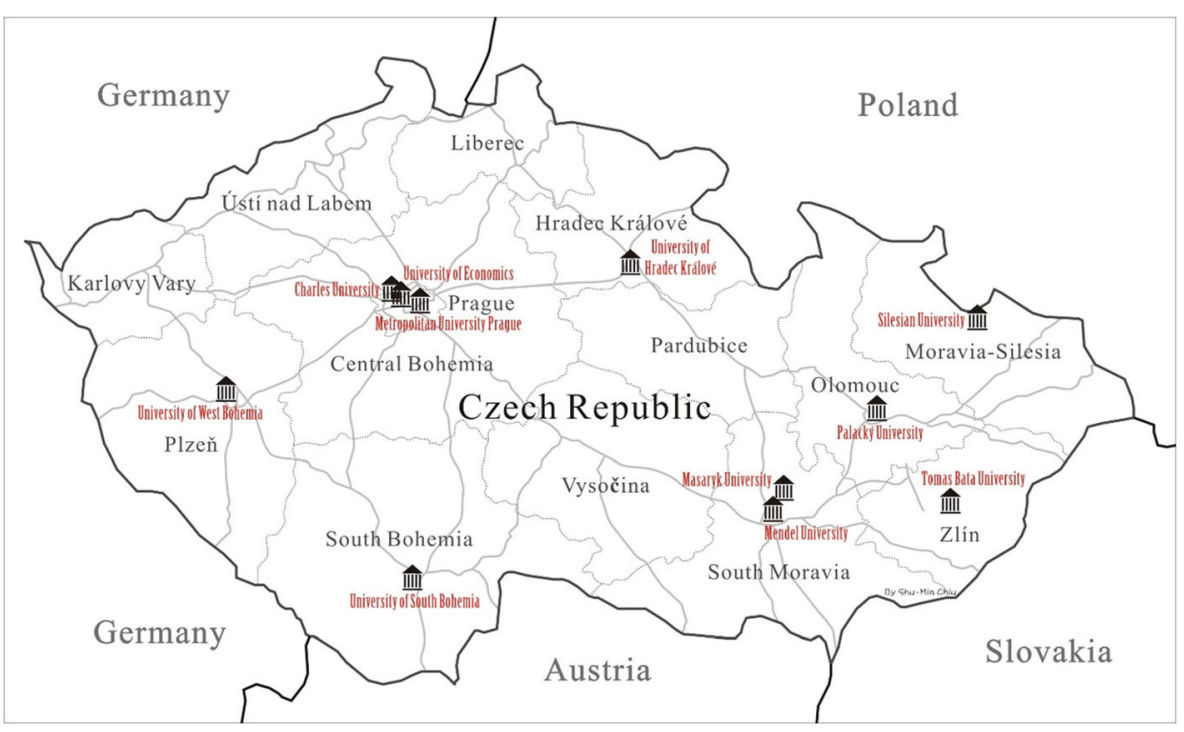

Fig. 2 Czech universities where the survey was conducted

50 Slovak students' observations in our data for analysis. There are several reasons for this decision. To begin with, Czechoslovakia used to be one country and had a peaceful split into two countries after the Velvet Revolution in 1993. Despite the separation, Slovaks are still quite present in the Czech Republic. Slovak students account for $4 \%$ of the whole student population in Czech universities. They pursue their education in the Czech Republic because they often consider the Czech educational system to be better than the one back home. Cultural and language similarities also help them to easily adjust to living in the Czech Republic. Many Czechs, especially those who were born before the 1990s, do not consider Slovaks to be foreigners. Among international students in Czech universities, Slovaks made up nearly two-thirds of them (Volynsky 2013). Recalling what was stated at the outset of this paper, Slovak policy towards China is more accommodating than the Czech policy, particularly when it comes to human rights issues. Whether this difference can be reflected in the thinking of Czech and Slovak respondents from our survey is intriguing. We kept the 50 Slovak observations in the data and let the statistical analysis reveal later whether Slovak respondents do think differently or similarly to Czech respondents. The final number of observations for analysis is 663 .

\section{Analysis}

STATA was used for statistical analysis. Sixty-five percent of the respondents are females (431), while 229 respondents $(34.5 \%)$ are males. The majority of them are aged between 20 and 29 years. A total of $92.5 \%$ (613) are citizens of the Czech Republic, while $7.5 \%$ (50) are from Slovakia.

Public opinions of another country are normally affected by a society's general predisposition towards that country as well as information disseminated about that 
country via education, media, or other factors in the surveyed country (Aldrich et al. 2014). Previously, in the literature review, we had an overview of the fluctuation of Czech society's views and experience with China in modern history. Here, we focus on looking at where our respondents obtain their information about China.

As citizens in democratic countries are becoming more and more autonomous in terms of where they obtain information (Aldrich et al. 2014), we asked respondents to list multiple sources of information. As Fig. 3 shows, TV, social media (i.e., Facebook, Twitter), and newspapers are the three main sources where respondents get their knowledge about China (Fig. 3).

Seventy-three percent of the respondents (484) had never heard of the $16+1$ initiative for CEE. Relatively speaking, China's OBOR initiative is more well-known than the 16+1 initiative. Most respondents (290) had never heard of OBOR but 277 did know about it (Table 1).

It is unclear why respondents would know more about the OBOR than the $16+1$ initiative. It could be that the former is more recent and leaves a much fresher impression in the young minds of the university students we surveyed. It could also be that OBOR is relatively more global than $16+1$ in terms of geographical coverage and thus has gained more prominence in media coverage. However, we do not have additional data to find out the cause here.

\section{General impression of China}

Each respondent was asked how much he/she likes China, Japan, Germany, the USA, Russia, and the EU. They had the options of choosing from 1 (very unfavorable) to 10 (very favorable). Japan stands out as the most favorable option while Russia is the least favorable (Fig. 4). For Japan, a lot of respondents are clustered around the numbers of 7 and 8. For Russia, most respondents are clustered around the numbers below 5, showing a general dislike for Russia. Attitudes towards China are somewhat in the

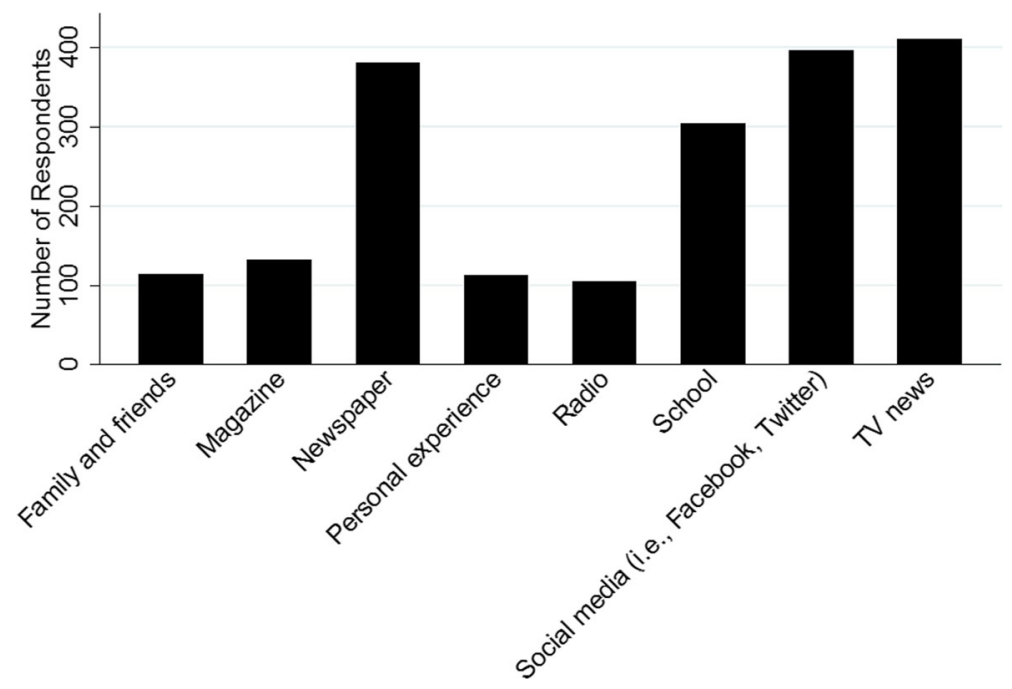

Fig. 3 Sources of knowledge about China 
Table 1 Have you heard of these initiatives from China?

\begin{tabular}{lll}
\hline & $16+1$ initiative for Central-Eastern Europe & One Belt One Road Initiative \\
\hline Heard of & $88(13.3 \%)$ & $277(41.8 \%)$ \\
Never heard of & $484(73 \%)$ & $290(43.7 \%)$ \\
Not sure & $85(12.8 \%)$ & $91(13.7 \%)$ \\
No answer & $6(0.9 \%)$ & $5(0.8 \%)$ \\
Total & 663 & 663 \\
\hline
\end{tabular}

middle, tilting slightly towards favoring China. Overall, however, Japan is still the most favorably perceived country.

Similarly, on a scale from 1 (no threat) to 10 (big threat), Russia was perceived by many respondents as the country most threatening to world peace while Japan was perceived as the least threatening (Fig. 5). Attitudes towards China were again somewhat in the middle, meaning that most respondents think China is neither particularly threatening nor peaceful.

Respondents were also asked about their trust in these five countries to act responsibly in the world on a scale from 1 (no trust) to 10 (wholly trust) (Fig. 6). In general, not many respondents would wholly trust any of these countries. But again, similarly to previous findings, Japan would still gain the most trust while Russia fared the worst. China fared slightly better than Russia, but was in general not very much trusted either.

Like Russia, the USS is deemed mostly threatening by the respondents. The political rivalry between the USA and Russia does not give the USA a good image. Also, there is an active and vocal pro-Putin lobby arising not only from paid propaganda agents, but also from some opinion leaders such as the current Czech president, Miloš Zeman, and the former president, Václav Klaus. The pro-Putin force tries to tarnish the US

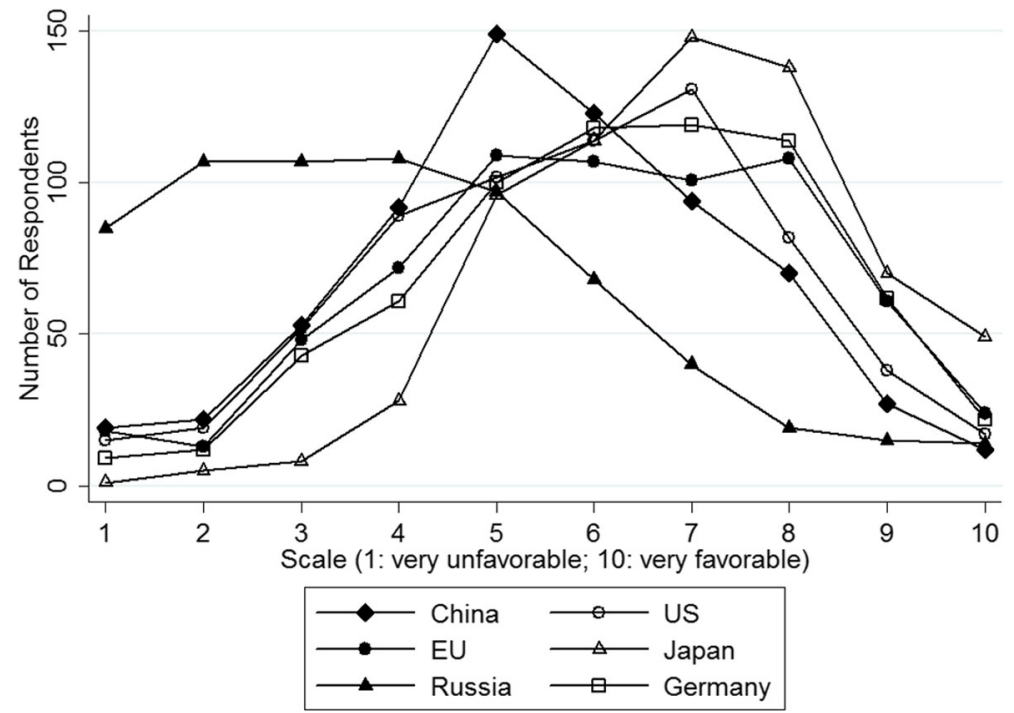

Fig. 4 How much do you like each of the countries or regions in the world? 


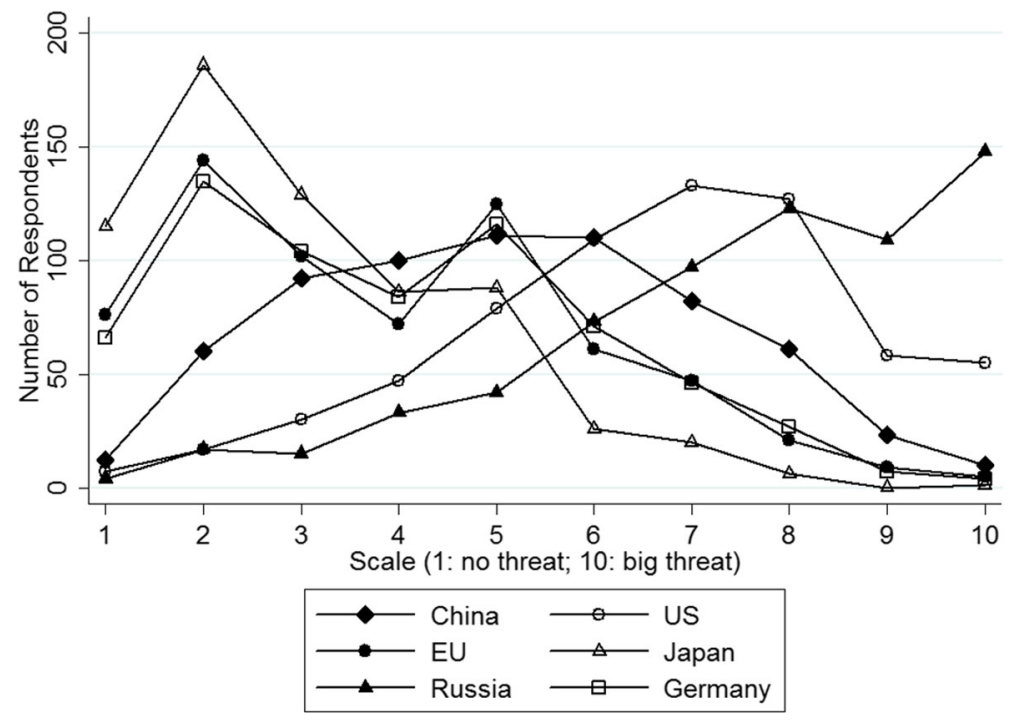

Fig. 5 How threatening do you think the following countries are to world peace?

image. This leads to a rather negative image of the USA in the minds of Czech people. This pro-Putin force, however, has not been able to persuade the majority of the society, who greatly dislike Russia. Hence, both Russia and the USA are perceived as threatening.

In sum, the results indicate that our respondents do not have good impression of Russia in general. Their impression of Japan is the best. The impression of China is somehow neither very negative, nor very positive. As for why Japan is deemed positively, Czech experts on Japan interpret this result as the overall ignorance of Czech citizens about Japan plus Japan's soft power influence to make it become an appealing country for

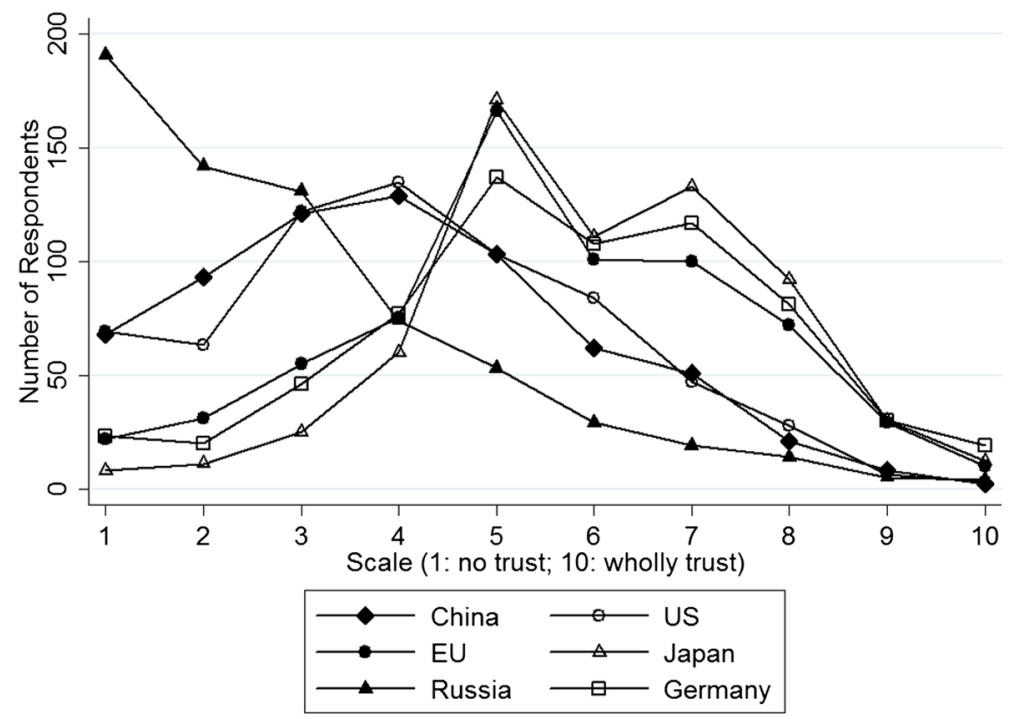

Fig. 6 How much do you trust each of the following countries to act responsibly in the world? 
Czechs. ${ }^{1}$ Czech people are more exposed to news about the USA and Russia than about Japan. News of political rivalries between the USA and Russia do neither country's reputation any good. News about Japan is relatively less and tends to be cultural. Apart from scholars and students of Japanese studies, the Czech public had few experiences of and information about Japan prior to 1989, so the current image of "modern" Japan has been constructed in the last three decades. Ordinary Czechs might know about Japanese electronics, trains, pop culture, robots, geisha, samurai, and anime, but they have little knowledge nor do they care about Japan's wartime atrocities. Some might know that there are constraints on Japanese military development, but the overall Czech impression of Japan is of a peaceful, respectful, and modern Japan, not a military aggressor or victim. In addition, the good quality of Japanese products is generally admired by Czechs, which is different from the negative Czech perception of products "made in China". ${ }^{2}$

Michal Kolmaš, a lecturer in International Relations at Metropolitan University Prague, comments that distrust and dislike of Russia are common among young people in the Czech Republic. It is usually younger people rather than seniors who dislike Russia. In Kolmaš' opinion, this is because of the expectations that seniors had prior to the Velvet Revolution. The older generation had believed that capitalism was going to bring the "American dream" to all of the society. Once this failed to materialize, it led to huge disillusionment about the new regime and system, which was difficult for seniors to adapt to. The older generation is thus more inclined to "cherish" the old days under Soviet rule, a sentiment that the younger generation does not share. ${ }^{3}$

China's image, while not the most negative, is not the most positive, either. The 1990s and 2000s were dominated by a media discourse which tended to depict China as an assertive communist power. "The then-president Václav Havel led the political legacy of human rights against communism, met with the Dalai Lama, celebrated Tibet's and others' nationalism, and thus greatly influenced our perception of China as a country famous mostly for human rights abuses. Although this position is slowly weakening in Czech foreign policy because of the new strategy of economic diplomacy, it is still very strong within humanistic circles, the intelligentsia, among celebrities and some political parties (Greens, some social democrats). I believe it has influenced current students' opinion during childhood," commented Michal Kolmaš.

\section{National power and influence on world affairs}

Impression does not equate to national power. Respondents are aware of China's growing national power. The USA is considered the most powerful, followed by China. The UK is perceived to be the weakest among these countries. Russia, Japan, and Germany's national power are perceived as being in between (Fig. 7).

Respondents were further given some expressions and asked which best describes China. ${ }^{4}$ The "rising dragon" was chosen to be the best description; 247 respondents out

\footnotetext{
${ }^{1}$ Communication with Dr. Michal Kolmaš (Metropolitan University Prague) on December 4, 2015.

2 Communication with Dr. Michal Kolmaš (Metropolitan University Prague) on December 4, 2015.

${ }^{3}$ Communication with Dr. Michal Kolmaš (Metropolitan University Prague) on December 4, 2015.

${ }^{4}$ As noted previously, the survey questions are mostly adapted from a long-term project of one of the authors. The same applies to the question concerning the best description of China. The sources of descriptions of China are drawn from stereotypical images of China in the global discourse, not from any specific Czech discourse.
} 
of $663(37.3 \%)$ indicated this option. This was followed by other descriptions, such as the "greedy snake" (156 respondents), the "crouching tiger" (115 respondents), the "stubborn bull" (70 respondents), the "sleeping lion" (60 respondents), the "adorable panda" (14 respondents), and the "slow-reacting turtle" (2 respondents).

When asked which country has the most influence in Asia, respondents clearly chose China as the winner (397 respondents). Russia was the second but, in fact, only $15.1 \%$ of the respondents chose Russia. Six percent of respondents chose the USA, followed by Japan, South Korea, and lastly the EU. When asked which country/region will have the most influence in Asia in the next 10 years, respondents again chose China as the evident winner. The other countries/regions that follow fare significantly worse in this regard, with the order of ranking as Russia, Japan, USA, South Korea, and the EU. The rankings for the current situation and for the future are quite similar (Table 2).

We also asked respondents to define China's rise on a scale from 1 (totally peaceful) to 10 (totally aggressive). Here, we observe that the respondents are highly divided. This is in line with existing observations of Czech society's stance towards China, which is fragmented. The society as a whole is undecided regarding the meaning of China's rise. Yet, with the majority of respondents choosing 7, and 7.621 being the mean of the data (Table 3), we conclude that there are still a lot of Czech citizens who do not believe that China can rise peacefully.

In response to the statement that "China will surpass the US and become the world's leading power", on a scale from 1 (totally disagree) to 10 (totally agree), our respondents again showed nuanced views. However, the mean of the data is about 5.968, suggesting that the overall tendency is to believe that China will surpass the USA as the world's leading power (Table 3).

There are two more questions related to China's power in the future. Respondents were asked their view of the scenario in which China becomes significantly more powerful economically and militarily than it is today. On a scale from 1 (negative) to 10

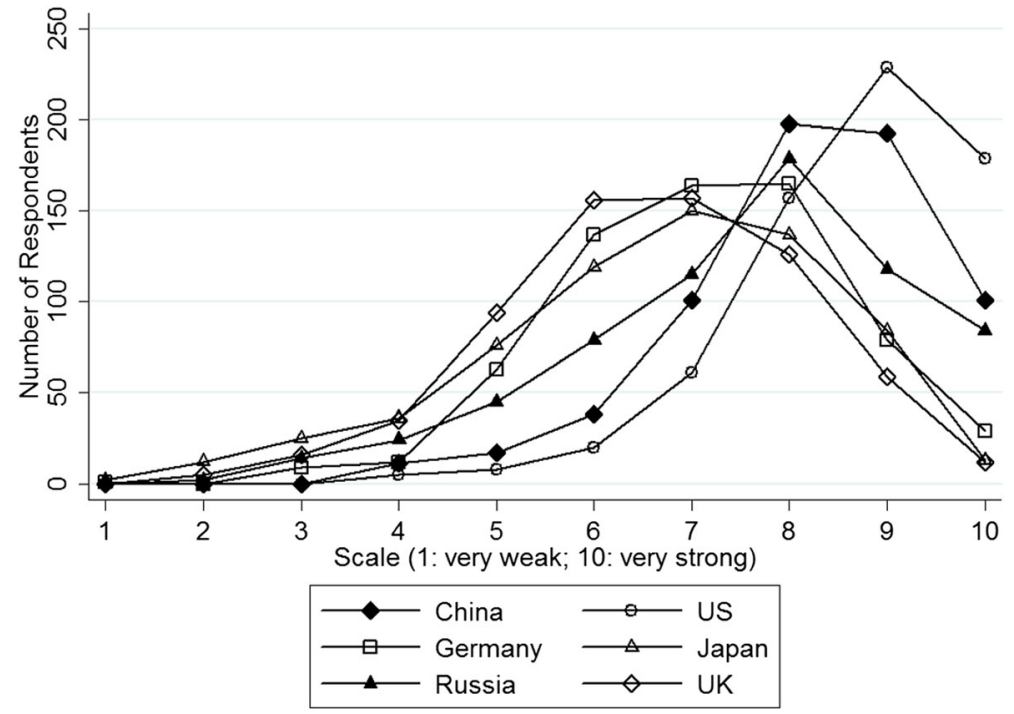

Fig. 7 Perceived national powers 
Table 2 Which country has the most influence in Asia?

\begin{tabular}{lll}
\hline & Now & In 10 years \\
\hline USA & $42(6.3 \%)$ & $18(2.7 \%)$ \\
EU & $2(0.3 \%)$ & $7(1.1 \%)$ \\
Russia & $94(14.2 \%)$ & $69(10.4 \%)$ \\
China & $451(68 \%)$ & $504(76 \%)$ \\
Japan & $30(4.5 \%)$ & $26(3.9 \%)$ \\
South Korea & $11(1.7 \%)$ & $14(2.1 \%)$ \\
No answer/unclear answers & $33(5 \%)$ & $25(3.8 \%)$ \\
In total & 663 & 663 \\
\hline
\end{tabular}

(positive), respondents were more positive towards China's increase in economic power than military power (Table 4).

Overall, these responses indicate that our respondents recognize the fact that China is rising. It is the most influential player in Asia. Albeit divided, the general tendency of Czech society is to believe that China will surpass the USA as the world's leading power in the future. Czechs cannot reach agreement on whether such development is peaceful or not. There is still a tendency to think that such a rise is going to be aggressive. A military rise is not welcomed as much as an economic rise.

\section{Relations Between the Czech Republic and China}

With regard to the Czech Republic's economic relations with foreign countries, respondents believe the closest relationship is with the EU (338), followed by Germany (251). China (25), Russia (15), South Korea (7), and the USA (1) are not perceived to

Table 3 Views on China's rise

\begin{tabular}{lll}
\hline & $\begin{array}{l}\text { How do you define China's rise: } \\
\text { peaceful or aggressive? (1: totally } \\
\text { peaceful; 10: totally aggressive) }\end{array}$ & $\begin{array}{l}\text { Do you agree that China will surpass the } \\
\text { USA and become the world's leading power? } \\
\text { (1: totally disagree; 10: totally agree) }\end{array}$ \\
\hline 1 & $8(1.2 \%)$ & $52(7.8 \%)$ \\
2 & $13(2 \%)$ & $45(6.8 \%)$ \\
3 & $43(6.5 \%)$ & $84(12.7 \%)$ \\
4 & $55(8.3 \%)$ & $79(11.9 \%)$ \\
5 & $81(12.2 \%)$ & $75(11.3 \%)$ \\
6 & $109(16.4 \%)$ & $81(12.2 \%)$ \\
7 & $165(24.9 \%)$ & $77(11.6 \%)$ \\
8 & $95(14.3 \%)$ & $81(12.2 \%)$ \\
9 & $45(6.8 \%)$ & $47(7.1 \%)$ \\
10 & $40(6 \%)$ & $38(5.7 \%)$ \\
No answer & $9(1.4 \%)$ & $4(0.6 \%)$ \\
Total & 663 & 663 \\
\hline
\end{tabular}


Table 4 If China becomes more powerful in these areas, what is your view?

\begin{tabular}{lll}
\hline & Economically & Militarily \\
\hline 1 (negative) & $41(6.2 \%)$ & $159(24 \%)$ \\
2 & $58(8.7 \%)$ & $99(14.9 \%)$ \\
3 & $86(13 \%)$ & $131(19.8 \%)$ \\
4 & $92(13.9 \%)$ & $111(16.7 \%)$ \\
5 & $148(22.3 \%)$ & $88(13.3 \%)$ \\
6 & $81(12.2 \%)$ & $27(4.1 \%)$ \\
7 & $78(11.8 \%)$ & $22(3.3 \%)$ \\
8 & $38(5.7 \%)$ & $12(1.8 \%)$ \\
9 & $14(2.1 \%)$ & $4(0.6 \%)$ \\
10 (positive) & $21(3.2 \%)$ & $4(0.6 \%)$ \\
No answer & $6(0.9 \%)$ & $6(0.9 \%)$ \\
Total & 663 & 663 \\
\hline
\end{tabular}

have close economic relations with the Czech Republic. No respondent believes that Japan has important economic ties with the Czech Republic at all. In the next 5 years, the EU (275) and Germany (183) are still considered as the ones which will have the closest economic ties with the Czech Republic, followed by China (102), Russia (48), South Korea (12), USA (12), and Japan (1). Previously, we have noted that our respondents are not familiar with Japan, except for some stereotypical impressions of Japanese culture. This result confirms that statement because respondents largely downplay the importance of Japan in the Czech economy. In fact, Japan is a major contributor of foreign direct investment (FDI) to the Czech Republic (Štrach and Everett 2006; Tseng 2013). As previously noted, South Korea's trade with the Czech Republic is increasing too (Dostál and Eberle 2015). Korea's growing influence, albeit small, is not well understood by the respondents either.

The respondents believe that Sino-Czech ties in the economic arena will grow in the next 5 years. If we read this result together with the perception of countries in the previous part of this paper, we can see that the perceived economic importance of China does not necessarily lead respondents to have a clear positive image of China in their minds. Respondents are clearly unaware of Japan's economic importance to the Czech Republic. But other factors, such as ignorance about Japan and fascination with Japan's other cultural powers, could lead respondents to favor Japan more strongly than China (Table 5).

As with its economic importance, the EU is perceived to have the closest military ties with the Czech Republic. After the EU, the USA is deemed to have close military relations with the Czech Republic, followed by Germany, Russia, and South Korea, although much less significantly. China and Japan are out of the picture. With regard to military ties in the next 5 years, the EU and the USA are still leading. However, compared with the current situation, more respondents believe that there will also be military ties with Russia, China, South Korea, and Japan (Table 5).

When asked, "How important do you think is for the Czech Republic to have strong ties with China and with the US?", respondents could choose on a scale from 1 (not at 
Table 5 Economic and military ties between the Czech Republic and foreign countries

\begin{tabular}{lllll}
\hline Region & $\begin{array}{c}\text { Economic ties } \\
\text { now }\end{array}$ & $\begin{array}{c}\text { Economic ties in } \\
5 \text { years }\end{array}$ & Military ties now & Military ties in 5 years \\
\hline USA & $1(0.2 \%)$ & 12 & $135(20.4 \%)$ & $135(20.4 \%)$ \\
EU & $338(51 \%)$ & 275 & $408(61.5 \%)$ & $359(54.1 \%)$ \\
Russia & $15(2.3 \%)$ & 48 & $35(5.3 \%)$ & $59(8.9 \%)$ \\
Germany & $251(37.9 \%)$ & 183 & $59(8.9 \%)$ & $58(8.7 \%)$ \\
China & $25(3.8 \%)$ & 102 & $0(0 \%)$ & $7(1.1 \%)$ \\
Japan & $0(0 \%)$ & 1 & $0(0 \%)$ & $2(0.3 \%)$ \\
South Korea & $7(1.1 \%)$ & 12 & $1(0.2 \%)$ & $8(1.2 \%)$ \\
Unclear/No & $26(3.9 \%)$ & 30 & $25(3.8 \%)$ & $35(5.3 \%)$ \\
$\quad$ Answer & 663 & 663 & 663 & 663 \\
Total & & & & \\
\hline
\end{tabular}

all important) to 10 (extremely important). Respondents seem to believe ties with both the USA and with China are equally important (Table 6).

When asked whether China's growing economic and military power is a good thing or a bad thing for the Czech Republic, from 1 (bad thing) to 10 (good thing), the majority of respondents gave an answer of 5 for both questions (Table 7). Five is a rather ambivalent answer as it denotes neither good nor bad. This might reflect the respondents' uncertainty about what China's economic and military power would mean for the Czech Republic. The mean for economic power is 6.769 while the mean for military power is 5.452. This shows that there is still a slight difference in perception between economic and military power. Respondents perceive China's economic power to be slightly more positive than its military power.

Table 6 How important do you think it is for the Czech Republic to have strong ties with China and with the USA?

\begin{tabular}{lll}
\hline & With China & With the USA \\
\hline 1 (not at all important) & $2(0.3 \%)$ & $3(0.5 \%)$ \\
2 & $4(0.6 \%)$ & $3(0.5 \%)$ \\
3 & $22(3.3 \%)$ & $11(1.7 \%)$ \\
4 & $49(7.4 \%)$ & $23(3.5 \%)$ \\
5 & $56(8.4 \%)$ & $55(8.3 \%)$ \\
6 & $144(21.7 \%)$ & $96(14.5 \%)$ \\
7 & $175(26.4 \%)$ & $168(25.3 \%)$ \\
8 & $121(18.3 \%)$ & $162(24.4 \%)$ \\
9 & $57(8.6 \%)$ & $85(12.8 \%)$ \\
10 (extremely important) & $27(4.1 \%)$ & $52(7.8 \%)$ \\
No answer & $6(0.9 \%)$ & $5(0.8 \%)$ \\
Total & 663 & 663 \\
\hline
\end{tabular}


Table 7 Is China's economic and military power a good thing or a bad thing for the Czech Republic?

\begin{tabular}{lll}
\hline & Economic power & Military power \\
\hline 1 (bad thing) & $37(5.6 \%)$ & $100(15.1 \%)$ \\
2 & $43(6.5 \%)$ & $65(9.8 \%)$ \\
3 & $54(8.1 \%)$ & $87(13.1 \%)$ \\
4 & $72(10.9 \%)$ & $102(15.4 \%)$ \\
5 & $142(21.4 \%)$ & $219(33 \%)$ \\
6 & $103(15.5 \%)$ & $43(6.5 \%)$ \\
7 & $78(11.8 \%)$ & $19(2.9 \%)$ \\
8 & $80(12.1 \%)$ & $14(2.1 \%)$ \\
9 & $29(4.4 \%)$ & $1(0.2 \%)$ \\
10 (good thing) & $15(2.3 \%)$ & $2(0.3 \%)$ \\
No answer & $10(1.5 \%)$ & $11(1.7 \%)$ \\
Total & 663 & 663 \\
\hline
\end{tabular}

Earlier in the paper, we mentioned that the Czech president Zeman was the only head of an EU state to have attended the V-Day parade in Beijing in 2015. On a scale from 1 (negative) to 10 (positive), respondents again appear to be fairly divided in their opinion on this incident. However, most respondents indicate 5, showing their middle ground position while the second largest cluster of respondents indicate 1, displaying their extreme negative view of the president's China tour (Fig. 8).

We did not ask respondents to make extra comments on this particular question. Interestingly, however, there were respondents who wrote down their comments in the questionnaires on this incident in particular. The opinions they expressed are similar. That is, they do not know much about this event and they have no problem with

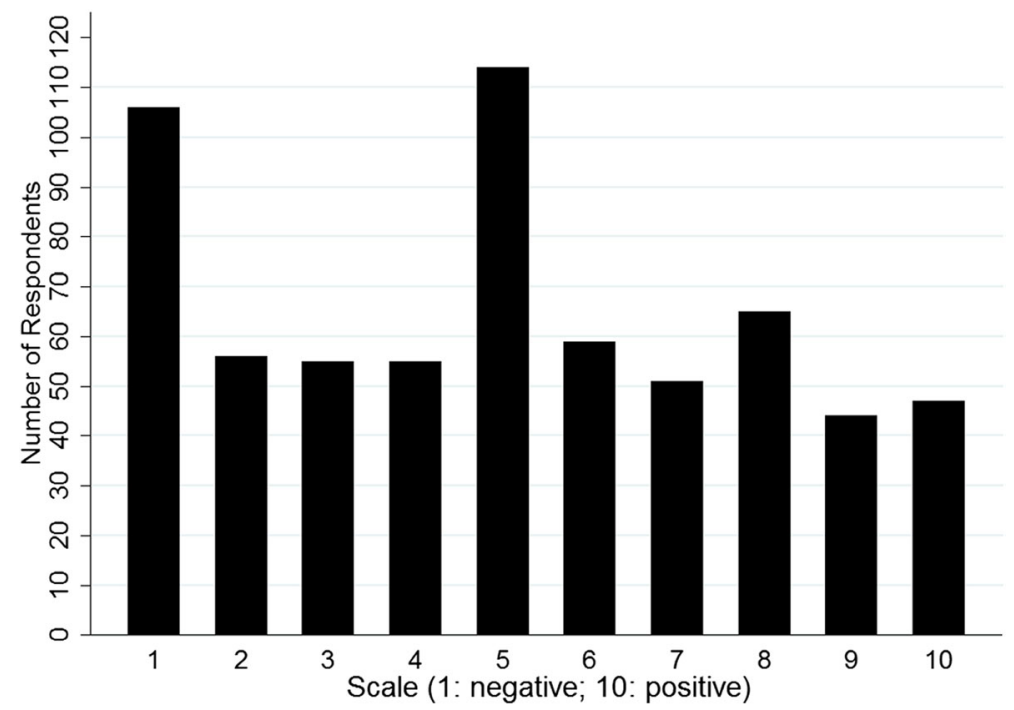

Fig. 8 Attitudes towards the Czech president's participation in the V-Day parade in China 
China's celebration. However, they do not hold a high opinion of the Czech president. So, their relatively more negative stance towards the issue does not target China, but the Czech president, whom they dislike because of his own bad reputation as a politician back home. This is somehow in line with Turcsanyi's (2015) observation that the Chinese media gave a fairly positive depiction of the Czech president's visit to China but the president himself faced criticism back in the Czech Republic.

\section{Conclusion}

While the Czech government wishes to get politically and economically closer to China, citizens are quite divided on various dimensions of issues concerning China, as shown in our survey. This is a pattern that continues from the past. The 2013 change of political landscape in the Czech Republic does not seem to have much altered the societal responses to China. As Turcsanyi comments on the divergent voices in the Czech Republic, "the divided public opinion means that every election can bring about adjustments in the country's Chinapolicy. While it is not clear whether the critical stances towards China actually affected the outcomes, it surely did not help either" (Turcsanyi 2014).

The gap between the preferences of decision-makers and lay people is not seen only in the China issue, it is also revealed in issues concerning Russia and Japan. Political elites are more divided towards Russia, with some who actually lean towards Putin. Ordinary citizens, however, clearly dislike Russia. As for Japan, elites have interests in strengthening ties with Japan. The general public is generally positive about Japan, but the source of that positive stance is due to a general lack of knowledge of Japan and one-sided information, namely the cultural information that Czech citizens normally get about Japan.

In fact, lack of knowledge is not a source of only "positively biased" views towards Japan, it is also a source of "negatively biased" views towards China. After all, geographically and culturally, the Czech Republic is far from these Asian countries. As noted previously, the reference point for making judgment on China and Japan can thus only be drawn from information fed to the Czech audience. In this context, the "neutral-but-leaningtowards- negative" views of China are nurtured by the China-bashing Czech media. The Czech media's discourse is embedded in the broader discourse of most liberal western democracies that is suspicious of China's handling of its human rights and minority rights issues. As Shih (2015) notes, their dislike of the Czech Republic's own communist past influences Czechs to dislike communist China. Whether there is a generational difference towards China, however, cannot be told from our data. Previously, we noted that the older generation in the Czech Republic is more positive about Russia than the younger generation. It is not certain whether a generational difference can be seen on the issue of China. Our data cannot answer this. We also tried to test statistically if other factors such as gender and citizenship (i.e., Czech vs. Slovak) made a difference in respondents' attitudes towards China. The conclusion is that neither gender nor citizenship plays a role.

Acknowledgements The authors wish to thank Ondrej Klimes and Martin Lavicka for comments on the early draft of this paper as well as numerous Czech scholars who have helped to facilitate the distribution of surveys in Czech Republic. This work was supported by the European Regional Development Fund Project number CZ.02.1.01/0.0/0.0/16_019/0000791 [Sinophone Borderlands-Interaction at the Edges].

The maps used in this paper are courtesy of Shu-Min Chyou. 
Authors contribution Yu-Wen Chen is Professor of Chinese Studies at the University of Helsinki in Finland, Hosting Professor of Asian Studies at Palacký University in Czech Republic and non-resident senior fellow at the China Policy Institute at the University of Nottingham in the United Kingdom.

Hao Yufan is the Director of Global Studies Program and Presidential Chair Professor at Chinese University of Hong Kong (Shenzhen). He was the Dean of Faculty of Social Sciences at University of Macau from 2013 to 2018. He obtained his PhD from the Johns Hopkins University School of Advanced International Studies in 1989 and has published more than 30 books and numerous journal articles on Chinese foreign relations.

Funding Information Open access funding provided by University of Helsinki including Helsinki University Central Hospital.

\section{Compliance with ethical standards}

Conflict of interest The authors declare that they have no conflict of interest.

Open Access This article is distributed under the terms of the Creative Commons Attribution 4.0 International License (http://creativecommons.org/licenses/by/4.0/), which permits unrestricted use, distribution, and reproduction in any medium, provided you give appropriate credit to the original author(s) and the source, provide a link to the Creative Commons license, and indicate if changes were made.

\section{References}

Aldrich J, Jie L, Liu K (2014) How do Americans view the rising China? J Contemp China 24(92):203-221

Chang VKL, Pieke FN (2018) Europe's engagement with China: shifting Chinese views of the EU and the EU-China relationship. Asia Europe Journal 16(7):317-331

Chen YW (2015) A research note on Central Asian perspectives on the rise of China: the example of Kazakhstan. Issues Stud 51(3):63-87

Chen YW, Duggan N (2016) Increased Chinese outbound tourism to Africa: understanding Africa's pull and China's push. J China Int Rel 4(1):45-66

Chen YW, Günther O (2018) Back to normalization or conflict with China in Greater Central Asia? Evidence from local students' perceptions. Problems of Post-Communism

Chen YW, Jiménez-Tovar S (2017) China in Central Asia: local perceptions from future elites. China Q Int Strateg Stud 3(3):429-455

Chen YW, Masch L, Finze K (2014) Using experimental methods to investigate discriminatory tendencies: a lesson report. J Soc Sci Educ 13(2):11-23

Cheng TH (2015) Between sinology and socialism: the collective memory of Czech sinologists in the 1950s. In: Shih CY (ed) Post-Communist Sinology in Transformation: Views from the Czech Republic, Mongolia, Poland, and Russia. The Chinese University Press, Hong Kong, pp 213-231

Chu YH, Liu K, Huang MH (2014) How East Asians view the rise of China. J Contemp China 24(93):398420

Dostál V, Eberle J (2015) Agenda for Czech foreign policy 2015. Association for International Affairs publication, Prague

Fallon T (2014) China's pivot to Europe. Am Foreign Policy Interests 36:175-182

Fürst R, Pleschová G (2010) Czech and Slovak relations with China: contenders for China's favour. EuropeAsia Stud 62(8):1363-1381

Green MJ, Szechenyi N (2014) Power and order in Asia: a survey of regional expectations. Center for Strategic \& International Studies, Washington D.C

Guo S, Feng GC (2012) Understanding support for internet censorship in China: an elaboration of the theory of reasoned action. J Chin Polit Sci 17:33-52

Hao YF, Su L (2007) Beautiful imperialist or war mongering hegemon: contemporary Chinese view of the United States. In: Farber D (ed) What they think of us: international perceptions of the United States since 9/11. Princeton Uninversity Press, Princeton, pp 74-94 
Hooijmaaijers B (2019) Blackening skies for Chinese investment in the EU? J Chin Polit Sci. https://doi. org/10.1007/s11366-019-09611-4

Katzenstein PJ (2012) Sinicization and the rise of China: civilizational processes beyond east and west. Routledge, London and New York

Lam PE, Ganesan N, Duerkop C (2010) Introduction: China and East Asia's mutual accommodation. In: Lam PE, Duerkop C (eds) East Asia's relations with a rising China. Konrad Adenauer Stiftung, Seoul, pp 7-42

Lin MSH (2015) Linguistic choices for the identity of 'China' in the discourse of Czech sinologists. In: Shih CY (ed) Post-Communist Sinology in Transformation: Views from the Czech Republic, Mongolia, Poland, and Russia. The Chinese University Press, Hong Kong, pp 27-40

Lomová O, Zádrapová A (2015) Beyond academia and politics: understanding China and doing sinology in Czechoslovakia after World War II. In: Shih CY (ed) Post-Communist Sinology in Transformation: Views from the Czech Republic, Mongolia, Poland, and Russia. The Chinese University Press, Hong Kong, pp $1-20$

Mearsheimer J (2010) The gathering storm: China's challenge to US power in Asia. Chin J Int Politics 3:381396

Nye J (2005) Soft power: the means to success in world politics. Public Affairs, New York

Shambaugh D, Yahuda M (2008) International relations of Asia. Rowman \& Littlefield Publishers, Lanham

Shih CY (2015) Introduction: an anthropology of knowledge in post-communist sinology. In: Shih CY (ed) Post-communist sinology in transformation: Views from the Czech Republic, Mongolia, Poland, and Russia. The Chinese University Press, Hong Kong, pp xi-xxvii

Shih CY, Yin JW (2013) Between core national interest and a harmonious world: reconciling self-role conceptions in Chinese foreign policy. Chin J Int Politics 6:59-84

Štrach P, Everett AM (2006) Japanese foreign direct investment in the Czech Republic: a motivational analysis. Probl Perspect Manag 1:22-31

Tseng SM (2013) Trade flows between Czech Republic and East Asia. Rev Econ Perspect 13(3):146-158

Tubilewicz C (2007) Europe in Taiwan's post-cold war foreign relations. Diplomacy Statecraft 18(2):415-443

Turcsanyi R (2014) China and the Visegrad countries: policies, goals and discrepancies. China Policy Institute analysis 6 October. https://blogs.nottingham.ac.uk/chinapolicyinstitute/2014/10/06/china-and-thevisegrad-countries-policies-goals-and-discrepancies/. Accessed 6 August 2018

Turcsanyi R (2015) Is the Czech Republic China's new 'bridge to Europe'?. The Diplomat. 12 September. http://thediplomat.com/2015/09/is-the-czech-republic-chinas-new-bridge-to- europe/. Accessed 5 August 2018

Volynsky M (2013) 'Slovak students look for better education and familiar culture at Czech universities. 16 March. http://www.radio.cz/en/section/curraffrs/czech-ministry-counts-cost-of-china-market-economystatus. Accessed 8 August 2018

Zhao, S (2015) Rethinking the Chinese world order: the imperial cycle and the rise of China. J Contemp China 24(96):961-982

Publisher's note Springer Nature remains neutral with regard to jurisdictional claims in published maps and institutional affiliations. 